\title{
Industrial Consortium to Foster Applied Research to Enhance Regional Eco- nomic Growth: a Successful Case Study.
}

\section{Dr. Osvaldo M. Micheloud, Tecnologico de Monterrey (ITESM)}

Dr. Osvaldo Miguel Micheloud Vernackt was born in Argentina in 1949; he graduated in Electrical Engineering from University of Rosario in 1973. In 1975 he ob-tained a scholarship to continue graduate studies at the University of Washington, in Seattle, and there he obtained the degrees of Master of Science (MSc), in 1978, and PhD in 1979, both in the area of Electronics and Automatic Control. Dr. Micheloud is currently the Director of the Industrial Consortium to Foster Applied Research for Economic Growth at Tecnológico de Monterrey; also he holds The Roberto Rocca Endowed Energy Research Chair and is the Director of the Master in Energy Engineering Program. In 1979 he got a design engineer position in an Argentinean-French Consortium of private Industrial companies. He worked for them twelve years. In 1991 he left this consortium and with a group of colleagues founded an Engineering Services Company for developing special equipment in the electronics area for industrial applications. Simultaneously to its industrial activities, in 1984 he began teaching at Instituto Tecnológico de Buenos Aires, ITBA. Later, in 1997, he became full-time professor in charge of the Department of Electronics Engineering. A year later, 1998, he was appointed Vice Rector for Academic Affairs of the same institution. Soon after joining the academy as a full-time professor, he got involved in various committees related to the continuous improvement of the engineering education and engineering accreditations. Among them, he was Vice President of the Federal Council of Engineering Deans of Argentina, CONFEDI, and for several periods he was reelected Director of its Educational Committee. Others organizations as the American Society for Engineering Education, ASEE and the IEEE counts him as one of his active members. In July 2006 he joined the Tecnológico de Monterrey, Mexico, for a sabbatical year, and shortly after arriving in Monterrey discovered an interesting niche in the area of training design engineers for the fast growing regional industrial companies. Working with a team of faculty founded an "Industrial Consortium" to support the training of new leaders in the fast growing area of new products "designed in Mexico". This program have probed to be an excellent mean to train people and get private funds to support applied research, in a highly sustainable environment as shown in the programs web page: http://www.mty.itesm.mx/dia/consorcio/ . In 2009 received the Teaching and Research Award at Tecnológico de Monterrey, and recently after this institution recognized his academic performance in teaching, research and academic extension, naming him Full Professor. At the same time he was named Roberto Rocca Endowed Research Chair Professor in the Electrical Engineering Department. In December 2010 he received from the Alumni Society of Mechanical and Electrical Engineering, IME, the recognition for being the teacher with the best IME spirit. He was elected by the students as the "Generations Best Professor" for four times in the last three years. In January 2013 he received the Romulo Garza Prize (about U\$D 18,500) for his contributions to develop applied research linked with the needs of the Mexican Industrial Sector. In addition, he was named member of the National Research Council (SNI in Spanish) by The National Council of Science and Technology of Mexico by its contribution to the scientific community in publications and academic products. Dr. Micheloud is a member of several professional organizations, including the IEEE, National Academy os Sciences of Mexico and ASEE. He is active in teaching and research, having about 30 master's thesis directed and $2 \mathrm{PhD}$ dissertations. He has more than 20 publications in conference proceedings and arbitrated journals. He is co-author of the book "Smart Grid: Fundamentals, Technologies and Applications" published by Cengage Learning in 2012. 


\title{
Industrial Consortium to Foster Applied Research to Enhance Regional Economic Growth: a Successful Case Study.
}

\author{
Dr. Osvaldo M. Micheloud
}

\begin{abstract}
Engineering research in higher education institutions has been traditionally financed by government grants. The areas of investigation were set by the researchers to fulfill their group /organization needs, including that of their PhD students who need to publish two articles in international journals as a minimum requirement to get their doctoral degree. As the resources to conduct research are provided by the governments, most of the prestigious research centers in Latin America are found in public universities, with very few exceptions in Brazil, Chile, Colombia and Mexico. On the other hand, universities struggle to get economic resources, beyond student's tuition and fees, to support their research and improve the quality of the education they deliver to be well positioned in the many university ranking systems produced by large international companies. Moreover, defining priorities in the research lines becomes a very hard task for deans and graduate directors, most of the time these budgetary discussions affect the organizational climate that is needed to ensure good results in scientific production. Tecnológico de Monterrey is the largest private university in Mexico with a top ranked engineering school. It is well known by the quality of their graduates ${ }^{(1)}$ and by the excellent connection with the Mexican industry. In particular, Monterrey is a large industrial city, located near the United States border, with two large and prestigious universities. The availability of large number of well-trained bilingual engineers and qualified labor force in the market are attracting a large number of high tech companies that are moving their manufacturing facilities and engineering design centers to this area. The fast growing engineering demand of well-trained people, capable of generating new products, improve process efficiency and create additional revenue sources for these companies, create a niche for an Industrial Consortium of Companies and University. This in turn attracts top engineering talents to
\end{abstract}


Monterrey and trains them to acquire the skills needed by these companies. A few of these talented students are enrolled in a full time graduate program with tuition and fees fully paid by the companies. Since the admission of the first generation of students, August 2008, the program keeps its steady growth and the companies are highly satisfied with the engineers they trained through this program. This paper describes, in details, the origin, motivation and implementation of the Industrial Consortium to foster applied research and enhance regional economic growth. In summary, first it is a well-rounded program where all the stakeholders win, and second it can be replicated in many regions of the world.

\section{BACKGROUND AND MOTIVATION}

In modern times industrial companies struggle to reduce costs and remain competitive in the market. The fast changing technologies and product innovations are also threatening them and, to survive and stay in business, they have to introduce new innovative products in the market and stay ahead of their competition. China and India are countries with excellent offers of cheap labor and well trained reverse design engineers, capable of reproducing most of the occidental products at a lower price. However, direct design of new products requires another type of personal ability, like deep knowledge of basic engineering fundamentals, new emerging technologies and modern engineering design tools. Monterrey grew up as an industrial city, mostly devoted to manufacturing products in large industrial companies in the area of steel, glass, beverages, electric transformers and, industrial products in general, with a solid demand for exporting due to an excellent commercial relationship with large economic markets.

The Mexican companies, willing to compete with China and India, started to introduce added value to their products, manufactured in Mexico, incorporating new designs and innovations to transform their products from "made in Mexico" to "designed and made in Mexico". This trend soon required better trained engineers in design of new products, and this sparked the idea of founding a Consortium with companies that have similar requirements for skilled people and to train all of them under the umbrella of a full time energy engineering graduate program. However, faculty know that real industrial experience seldom comes in books or scientific papers, so a decision was made to ask companies to support the students, and faculty, with their top engineers as mentors in their thesis projects. On the other hand, the 
university understands that there is a need to attract top talent from all over the world willing to work hard in applied research to get new patents, publish scientific papers and create wealth for the supporting companies. With all these objectives in mind a group of five companies founded the Industrial Consortium to Foster Applied Research in Mexico in February 2008.

\section{UNIVERSITY-INDUSTRY PARTNERSHIP THE SYNERGY THAT MAY CHANGE THE INDUSTRIAL FUTURE}

It is well known that most of the top engineering students receive good work offers from leading companies at the time of their bachelor graduation, but a few of them reject these offers, as they are willing to pursue graduate studies. These students are not attracted by just a good salary; their driving force is to acquire new theoretical knowledge that they can apply to design new high tech products. Hard workers, innovators, strong in math, physics and engineering fundamentals are common characteristics of this small group of people. Additionally, most of them look at well-known international universities as the place to continue their education and perhaps, after graduation, emigrate to get more challenging working positions.

The challenge is to retain these talents in the country and keep them working in local companies applying their knowledge to create new innovative products and improve the international competitiveness of the region. In the long term, those countries that will be able to retain their talent, will experience a steady economic growth that will warranty sustainability.

In response to these facts, Tecnológico de Monterrey created the Industrial Consortium to Foster Applied Research and attracts top talent, searching for a top graduate program, and asked the companies to first select and second retain the ones that best fit their needs. After selecting the best candidates the companies assign them to a full time graduate program that will prepare the students to face the challenges and solve the problems that the company will assign to them the very first day at the program. The Industrial Consortium started class activities in August 2008 with thirteen students, selected by five companies. Before then, it took about one year of negotiations to establish what areas of the engineering field the Consortium should focus on and to work out the legal framework especially around intellectual property.

Even before the first generation of students graduated, all five companies were convinced that the Consortium's original idea was working very well for them and synergy among companies was found which enhanced the program. The young talents was happy working with 
experienced engineers provided by the sponsoring companies and closely assisted by faculty, finding new areas to develop/improve products in a very effective way. This relationship enriches the educational process and provides tangible benefits for all stakeholders. Their impact to the business was clearly a successful indicator that the solution to the challenges that led to the foundation of this Industrial Consortium was appropriate.

\section{ENERGY, THE BEST FIT TO FULLFILL THE INDUSTRY NEEDS}

One of the great challenges during the inception of the Consortium was searching for an area that would fulfill the needs of most companies willing to invest in training new talent, and at the same time, sharing educational resources to cut cost. It was clear to the sponsor companies that the selected area should be sufficiently attractive for all of them, but not too specialized, to allow the synergy of sharing common computer platforms, expensive software packages, courses, seminars, and other educational aids like laboratories. In addition, a "design center" was recreated with adequate office space to accommodate the students in a real industrial setting. An atmosphere of hard work and collaboration among students was created.

Energy Engineering and Energy Efficiency were finally the selected research areas. All partner companies agreed that under this umbrella they were able to accommodate many different engineering projects, ranging from those heavily oriented to electrical power systems analysis in presence of large nonlinear loads, like Electrical Arc Furnaces for the steel making industry, to combustion in large steam power plants.

Design of new electrical devices, electronics converters, thermal equipment, chemical processes, and renewable energy systems are active areas were the students are currently working sponsored by the partner companies and under the advice and supervision of their respective company mentors and faculty. More recent projects can be found in reference \# 2 .

Several scientific contributions, like patents, new products and indexed publications, were recently produced. Additionally, significant energy savings were reported by a company that focuses their research in the area of Electric Arc Furnaces for the steelmaking industry. 


\section{THE STAKEHOLDERS: COMPANY, UNIVERSITY AND STUDENTS}

The three main stakeholders in this consortium are: company, university and students. A successful program needed to address all their collective needs.

1. Companies have the necessity to develop technologies to compete globally. They cannot afford to keep all their engineers well updated with new emerging technologies. They cannot afford to have state of the art technologies, in computing platforms and design software licenses, to support the limited design capabilities of their production engineers. They have a hard time recruiting top young talent that will support their activities and keep them updated with new technologies.

2. Prestigious universities have graduate programs that attract talented people driven by their need to acquire new knowledge. All graduate students enrolled in the leading graduate program spend one third of the time conducting research in the field of their master/ $\mathrm{PhD}$ thesis. Defining the area of research, at the beginning of their graduate program, becomes a hard task for the student due to his/her lack of industrial experience. Expensive computing platforms and software licenses are available and shared with many other programs. Faculty feels more comfortable lecturing the material in a textbook and facing, in class, problems with well-known solutions.

3. Top students like to devote all their time to study mandatory courses and conduct research in his/her area of interest when time permits. They do not want to have the need to work while studying. They may ignore what is happening in the local industries and how their time devoted to research could generate wealth in regional companies.

Considering the above facts, interest and preferences, the Industrial Consortium was the answer to all of them. Top company engineers are willing to improve their knowledge and share industrial experience with young students, additionally they know which are the company needs and the economic impact of many areas that require improvement, but they do not have the time and knowledge to conduct a deep study using modern simulation tools. The faculty is sometimes afraid to work in solving real company problems, but when supported by company technology leaders, they will accept new challenges to establish good ties with industry. Students get their

projects defined from the very first day in the program and have the certainty that their research work will contribute to the economic development of the region. Additionally, he/she will 
receive from the company an economic support, equivalent to the salary of a junior engineer, as well as the university that will collect full tuition and fees from the company.

The reader might be wondering why a company would invest so much to support a program like this. Well, the answer became obvious after the graduation of the program's first generation of students. All of them were hired by the companies that supported them and are still working in the same area in which they were trained at the university. The transition from university to industry was seamless for these students, with no need for further industrial induction courses or company training.

\section{COMPANY AND UNIVERSITY COMMITMENTS}

To secure the formation of human resources, responding to the real needs of the industrial partners, specialized in the design of middle and high technology equipment, capable of performing research, generate and transfer practical knowledge a group of Committed Industrial Companies decided to strengthen the Engineering Graduate Programs, by strongly bonding them with the needs of local industry by agreeing in the following actions:

a. Integrate, as partners, a fellowship of companies oriented to design new high tech products and incorporate them in their manufacturing chains to nurture the economic growth of the region.

b. Participate in the student selection process of those who wish to enter the graduate program, identifying those who possess a suitable industrial profile to meet the requirements of their companies and those who also had a distinguished performance in their bachelor studies.

c. Support the best talent that, assisted by the engineering staff and human resources personnel of the partner companies may recruit at the top engineering schools of the country. The cost of the tuition and personal expenses, in present times (2015), is about 25,000 U\$D/year per student at the host university.

d. Additionally assist with economic support, and only on very particular cases, to those students that after identifying top specialists in his/her area of research in leading institutions of the world, they manage to establish a sound working relationship with them, to spend one semester working abroad as visiting students.

e. Provide innovative research and development projects to involve graduate students and facilitate their top design engineers, to serve as mentors for them and follow closely their progress and thesis. 
f. To motivate their own engineers in participating in the process of forming graduate students by lecturing some classes in their field of expertise in team teaching with full-time faculty.

g. To define the basic areas of interest of the graduate program that will be used by the university and the companies themselves in the process of promotion and recruitment of new students.

h. To participate with their engineers in the periodic meetings of the Industrial Consortium to support in defining the courses which the selected students must take for the whole 18/24 months while they remain at the university.

i. To contribute economically with the student recruitment process, research activities and trips to conferences by paying "membership fees" that are administered to cover said expenses. The cost of this membership was set to five thousand $(5,000)$ USD per student for the whole duration of the students program.

j. To help the university widen its network amongst their contacts with the best engineering schools in the country, by jointly calling for talent to enter this graduate program sponsored by them.

Additionally, the university, as coordinator of the fellowship, commits to:

1. Attract the best talent, both in national and foreign universities, to fill the places that the Consortium defines for their needs. This implies travelling to make presentations of the program, and the sponsoring companies, at major events at different engineering schools.

2. Create a work environment, based on a culture of effort, dedication and collaboration, which facilitates knowledge generation and ideas that can be turned into products with a high added value for the companies in the Consortium.

3. Provide adequate space for study, meetings and properly equipped laboratories so the students, teachers and the companies' mentors may perform their work in an efficient way.

4. Protect, in a secure and efficient way, the intellectual property of every company that takes part in the Consortium.

5. Recognize the companies supporting the program by including their names and logos in every promotional brochure of the graduate program.

6. Promote new research projects which allow anticipating the acquisition of new knowledge in areas which may benefit the regional economic growth by creating products and systems of high added value. 
7. Organize two annual meetings, with the participation of all Consortium members, to evaluate the results of the graduate program, performance of the students and teachers, student recruitment, and define new goals and objectives for the next semester. Finally the consortium's director must present an account audit for all company funds.

8. As a recognition to the trust that these industrial companies place in the educational institution, the university assumes responsibility of paying the wages and assign the necessary academic load to this activity so their best professors may directly contribute to the formation of these students in the graduate program and to keep open communication channels to assure that teaching and research responds effectively to the companies' needs.

\section{KEY POINTS AND MAIN DIFFERENCES WITH TRADITIONAL ENGINEERING GRADUATE PROGRAMS}

Thanks to the economic support provided by companies the students receive a monthly stipend equivalent to the starting salary of any good engineer in the regional companies. In addition, he/she gets tuition, fees and medical insurance expenses fully paid by the sponsor company. Several courses are taught in "team teaching" by faculty and leading engineers from the sponsor companies. Every week the students take part in technical debates/seminars, where they present the progress of their research work and an open discussion is generated to train them in collective learning techniques. In addition they are trained to do high quality technical presentations improving their communication skills. Those students that acquire excellent communication abilities and their research projects are relevant, are encouraged to publish the results in journals or present the work at international conferences to establish ties with world leaders in the area of their research.

The final admission in the program is granted by the sponsor companies. All suitable candidates must have outstanding records from his/her previous engineering studies, advanced English proficiency, sound knowledge in basic sciences, such us physics, math and computing, in addition to master their main area of expertise, like electrical, mechanical, electronics, etc. Students must adhere to rules of the Consortium specially those about intellectual property rights. All candidates must present and pass with excellent records the admission graduate examination prepared by the educational institution. 


\section{LESSONS LEARNED}

The Industrial Consortium is a successful program which has demonstrated that investment in applied research can be sustainable, cost effective and strategic for an international company willing to settle in a foreign country. A research center, associated to an industrial company, is like the roots of a tree, needed to be feed by innovations in new products and to monitor the evolution of disruptive technologies driven by competitors that could threaten the stability of the company.

In the herein presented Consortium, after six/seven years of hard work, the number of students remain limited by the number of faculty, however, the number of companies doubled from the original five. The complexity of the projects is increasing with time and new students are faced with more challenging projects. This requires more time and dedication from the students, mentors and faculty. Company mentors are quite limited in time to assist their students and attend the weekly session of debate organized by the consortium. However, several companies require that the faculty advisor spend more time, not only in helping the student, but also to be more involved with the company mentors by paying frequent visits to meet and discuss alternative solutions with them. The number of graduate students that remain working with the sponsor company is directly proportional to the time the company spent in helping the student while in the program. One challenge is that the program does not have any extra funds to reward faculty and/or mentors and, as said before, the amount of time required to mentor these students is considerable if added to the daily working load of engineers and faculty.

\section{CONCLUSIONS}

The Industrial Consortium is now a well-established and sustainable program. It is another potential solution to the old problem of connecting educational institutions with local industry. At the same time, it creates the bridge between the creativity of young talent and the local industry needs to create wealth in the region. It stimulates student actions to better understand the real engineering projects and encourages the companies to invest in applied 
research. It also helps to keep company engineers updated with new technologies and faculty connected to the real world problems. In summary, it is a well-rounded program where all the stakeholders win and it can be replicated in many regions of the world.

\section{ACKNOWLEDGMENTS}

The author would like to thank the first five founder companies that trusted this idea by supporting the first 13 students. They are: Ternium, Schneider Electric, Prolec GE, Ami GE and Cerrey. Also extend this acknowledgment to Nutec Bickley, Acciona Energy, Diram, TenarisTamsa and Tenova HyL. Finally, this work would not have been possible without the permanent support of Prof. Federico Viramontes Brown and our faculty, company mentors and students

enrolled in the program. To all of them, thank you for helping prove that industrial applied research can be sustainable and can create wealth to improve the quality of life in the region.

\section{REFERENCES}

[1] "QS Latin America University Rankings 2014" http://www.topuniversities.com/university-rankings/latin-american-universityrankings/2014\#sorting=rank+region=+country $=+$ faculty $=+$ stars $=$ false + search $=$

[2] "Industrial Consortium to Foster Applied Research \& Roberto Rocca Energy Research Chair" http://www.mty.itesm.mx/dia/consorcio/ 